\title{
Under the microscope- An examination of the supports for ethnic entrepreneurs in
}

\section{Ireland}

\section{Purpose}

Because entrepreneurs operate in a world of uncertainty, the ability to analyse a situation, extract the important and ignore the superfluous, compare potential outcomes, and extrapolate from other experiences to the current one is vital. Researchers have identified several skills an entrepreneur requires to operate their business and the focus of this paper is to examine if the training and support necessary for entrepreneurship to occur within ethnic communities exists in Ireland.

\section{Design/methodology/approach}

A survey was administered to support agencies and established ethnic entrepreneurs in Ireland. Responses from eight support organisations and 36 ethnic entrepreneurs were received.

\section{Findings}

Targeted programmes offered by service providers included programmes in foreign languages; providing literature in foreign languages; and specially designed seminars for ethnic entrepreneurs. Of the established ethnic entrepreneurs, the majority indicated that, although they have deficiencies in their skillset they did not avail of programmes because they were unaware of them.

\section{Originality/value}

Irish service providers need to provide additional services to ethnic entrepreneurs to be on par with their EU counterparts. Irish service providers need to provide general and targeted training programmes through minority languages. If Ireland wants to continue being known as the 'land of a hundred thousand welcomes' and be able to support the muchanticipated asylum seekers who may choose entrepreneurship as a career option, it needs to 
consider the adoption of the recommendations of this study and provide better tailored services for the ethnic entrepreneur.

Keywords: Ethnic entrepreneurs, entrepreneurship supports, Ireland, training, skills. 


\section{Introduction}

Whether it is the result of demographic change, technological innovation, market change, wars and conflicts, or changes in the institutional framework, a growing number of ethnic entrepreneurs have emerged throughout Europe (Rath and Swagerman, 2011). For this study, the term ethnic entrepreneur refers to individuals who have similar national backgrounds or migration experiences (Waldinger et al., 1990) and who establish a business in their new host country. Theorists have identified that the reasons for the emergence of ethnic entrepreneurs in Europe could be due to necessity or opportunity, also known as push/pull factors. Typically, 'push/necessity factors' include the lack of employment opportunity in the host country (Lassalle et al., 2010); language barriers are experienced thus jobs are limited (Oliveira and Rath, 2008); the inability of employers to recognise foreign credentials (OECD, 2010); and the lack of contacts in the domestic market so migrants are not aware of job opportunities. Experiencing some of these factors result in entrepreneurship being the only opportunity for survival (OECD, 2010; Reynolds et al., 2005). According to RETHE (2010, p.50) the reason why ethnic entrepreneurs in Europe establish a business is due to 'lack of other employment alternatives' and when they do start a business, they are typically life-style firms (laundry, restaurants, etc.) employing less than five people. Conversely pull/opportunity entrepreneurs are entrepreneurs who freely decide to start a business to take advantage of a business opportunity (Basu et al., 2008; Chrysostome and Lin, 2010; Keh et al., 2002; McMullen and Shepherd, 2006). According to Chrysostome (2010, p.138) for some ethnic entrepreneurs, seeking business opportunities is part of their culture, so it is the norm for them to start a business when they are settling down in their host country.

Ireland ${ }^{1}$ is at its heart an entrepreneurial nation and entrepreneurship is an active career choice for many Irish people. Having emerged from a particularly bad global financial crisis,

\footnotetext{
${ }^{1}$ Ireland here refers to the Republic of Ireland and does not include the six counties of Ulster.
} 
it is imperative that Ireland taps into this entrepreneurial spirit, to create opportunities, utilise its scarce resources and create the enterprises of the future. Furthermore, Ireland needs to encourage and harness the entrepreneurial spirit and potential of all people living within the country including those individuals who are natural citizens and those for whom Ireland has become home (Fitzsimons and O'Gorman, 2009). In order to enable and support this entrepreneurial spirit this paper poses the following research question: Does Ireland provide the training and support necessary for entrepreneurship to occur within the ethnic communities that call Ireland home?

\section{Ethnic Entrepreneurship and its Emergence}

Very often researchers will use the terms ethnic, minority and immigrant interchangeably; however, there are subtle differences between them. Ethnicity refers to a sense of kinship, group solidarity, common culture, and self-identification with an ethnic group (Hutchinson and Smith, 1996). In the context of ethnic entrepreneurship, 'ethnic' refers to 'a set of connections and regular patterns of interaction among people sharing common national background or migration experiences' (Waldinger et al., 1990, p.33). Chaganti and Greene (2002) identify immigrants as recent arrivals in a country however Rath (2006) states that defining immigrants is contingent on the specific national incorporation regime and differs from country to country. Basu and Altinay (2002) define minority entrepreneurs as being business owners who do not belong to the majority population. They further explain that a minority may not (necessarily) be an immigrant and may not share a strong sense of group solidarity with an ethnic group, in terms of a shared history, language or religion. The OECD (Ahmad and Seymour, 2008) have defined migrant entrepreneurs as those foreign-born business owners who seek to generate value through the creation or expansion of economic activity, by identifying new products, processes or markets. The variety of definitions indicate the interest in ethnicity and minority 
entrepreneurship and this paper will adopt the broad title 'ethnic entrepreneur' as an allencompassing term.

So, what motivates ethnic entrepreneurs to establish a venture? Many researchers have identified barriers that non-natives face including blocked opportunities in the labour market (Volery, 2007, p.2); lacking educational qualifications or not having the testimonials citing those qualifications (Birdthistle, 2012); and lacking the relevant social networks for gaining access to information about vacancies in the job market (Rath, 2010). By being entrepreneurial, they create their own employment and can overcome some of the many barriers that they face in relocating to another country. A domino effect is, if these businesses become successful, ethnic entrepreneurs have the opportunity of becoming employers themselves, thus creating jobs, adding to social and economic growth and sustainability. This results in a benefit for the ethnic entrepreneur's immediate family, relatives and then, on a larger scale, the wider community and the host nation. An additional impact is that through job creation, ethnic entrepreneurs help to alleviate unemployment among immigrants (Rath, 2010).

Ethnic entrepreneurs may provide services and/or products that native entrepreneurs may not be able to offer, as they are more likely to have expert knowledge on specific demands or access to sources of supply relating to foreign products/services. Portes (1995) labelled this as 'hard-to-copy' expertise and can be based on first-hand knowledge and/or experience from their home country. Pang and Rath (2007) agree that ethnic entrepreneurs are important to the social fabric of their community thereby sustaining the civic society in which they operate. Kurtoglu (2007, p.428) echoes this sentiment by stating that this is achieved by ethnic entrepreneurs adding vitality to the locations they establish in and by having a 'clear stake in the prosperity, accessibility and safety of their community'. All these points confirm that the inclusion of ethnic entrepreneurs in a nation's society and its entrepreneurial ecosystem can 
only lead to positive outcomes, both for the host nation and the community being served by the ethnic entrepreneurs.

\section{Trends in Migration to Ireland}

Ireland has been a country of destination for ethic entrepreneurs since its inception. In 1938, a year after the Irish Constitution was ratified, an Austrian named Marcus Witztum opened Les Modes Modernes Hat Factory and Emil Hirsch from Austria (Muchitsch, 2006) established a ribbon factory. Yet historically, Ireland was predominantly a country of emigrants, whereby Irish people relocated to many countries. This was most evident in the 1980s, which was a decade of high unemployment with high emigration peaking in 1989 when over 70,000 left the country (Ní Laoire, 2004). However, because of growth and prosperity during the Celtic Tiger $^{2}$ years, Ireland attracted more immigrants than it historically did, and Ireland admitted more migrant workers per head of population than any other EU nation, since the union enlarged (Mac Cormaic, 2008). For example, in the period 1995-2000, approximately 250,000 persons migrated to Ireland, of whom about half were returning Irish and the rest were Europeans, Americans or asylum seekers. In 1992 Ireland received 39 applications for asylum, this figure steadily rose to 424 in 1995 and 1,179 in 1996 (Ward, 2001). However, asylum applications proceeded to double and later triple throughout the so-called boom years, peaking in 2002 with 11,634 people (Reception and Integration Agency, 2011).

In 2017, Ireland had some 2,910 applications for asylum. Most asylum seekers were from Syria (545 persons) of which none were refused asylum in Ireland (Irish Refugee Council, 2018). As is evident from Table 1, very few applications for asylum are rejected. Figures provided by the Department of Justice reveals that there were 599 new asylum claims in the first two months of 2018 compared to 387 for the whole of 2017 (Lally, 2018). As of November 2018, the International Protection Office (2019) has indicated that Ireland has received some

\footnotetext{
${ }^{2}$ Celtic Tiger is a term referring to the economy of the Republic of Ireland from the mid-1990s to the late-2000s, a period of rapid real economic growth fuelled by foreign direct investment.
} 
3,324 applications for asylum. According to the figures provided by the Central Statistics Office (2018) for 2018, there was a 6.7 per cent increase in terms of the number of immigrants to Ireland (from 84,600 in 2017 to 90,300 in 2018), while the number of emigrants declined over the same period. Some 28.4 per cent were returning Irish nationals, with a staggering 31 per cent classified as coming from 'Rest of World' i.e. outside of the European Union. Of these immigrants, they are highly educated with 49 per cent having a third level qualification (Central Statistics Office, 2018).

\section{$<<$ INSERT TABLE 1 HERE $>>$}

Since Ireland has opened its doors to non-nationals to reside in the State, the entrepreneurship policy and supports tailored for the ethnic entrepreneur are examined from an EU perspective.

\section{Policy and Best Practice in Europe}

To increase the success of entrepreneurial measures, appropriate policies and programmes should be developed to spread the entrepreneurial culture and encourage entrepreneurs. In a policy setting, an increasing convergence can be observed of innovation and entrepreneurship policy. Policy measures have shifted their focus from hard, infrastructurebased programmes to a soft-policy approach focussing on the individual. Many policies are designed with the entrepreneurial system in mind and targeted towards the owner-manager, but most policies, which are aimed at business creation, are directed towards the individual (European Commission, 2000; Vonk and Ribbink, 2008). In this case, the support measures are focussed on initiatives such as training, one-to-one advice and skills development.

In Europe there are 146 policy measures which offer services (such as training, counselling and information services) to ethnic entrepreneurs enabling the strengthening of human, social or financial resources which leads to empowerment (European Commission, 2000; Vonk and Ribbink, 2008). Fewer measures focus on providing financial services, but in fact, many programmes facilitate access to finance by strengthening the entrepreneurs' skills 
and knowledge. Occasionally, measures provide material assistance, for example incubator services. Nearly half of the policy measures examined by Vonk and Ribbink (2008) and the European Commission (2000) identified that they had a more general focus and they serve both native-born entrepreneurs and ethnic entrepreneurs; the remaining half of the policy measures or support schemes focus entirely on ethnic entrepreneurs. Vonk and Ribbink's (2008) study found that there were 63 policy measures throughout Europe which targeted both native-born and ethnic entrepreneurs, 76 targeted only ethnic entrepreneurs and seven specifically targeted the Roma Community. Some of the general policies are identified below:

COSME: COSME replaces the Competitiveness and Innovation Programme and it aims to promote entrepreneurship, improve the business environment for SMEs and boost their competitiveness and has some $€ 2.3$ billion to support SMEs. The policy measures associated with this programme include access to finance, access to markets, creating better framework conditions for competitiveness and encouraging entrepreneurship. In relation to finance, the Loan Guarantee Facility (LGF) will provide guarantees to financial institutions so they can provide more loans and lease finance to SMEs. COSME has been in operation since 2014 and it has its own strengths and weaknesses. Its strengths lie in being non-discriminatory in terms of location and size, meaning that it assists any size of SME in any part of the European Union (Mahieu et al., 2017). Furthermore, it assists SMEs with accessing relevant finance along the lifespan of the entrepreneurial firm. Another strength lies in the provision of, and access to, relevant practical information for the SMEs needs.

However, COSME does have its weaknesses and a key one lies in its 'non-targeted' approach. The programme has two major actions: the loan guarantee fund and the Europe Enterprise Network. These actions form a major part of COSME's budget and target all SMEs without making distinctions to reflect the programmes 'inclusive and sustainable growth' and 'assisting in achieving global competitiveness' (Mahieu et al., 2017, p16). As Mahieu et al., 
(2017, p.16) posit 'these two major actions can therefore create only 'unintended' effects in those two areas and as a result the relevance of COSME for policy objectives such as gender mainstreaming or climate change is limited'.

An example of best practice concerning this policy includes the Slovene Enterprise Fund (SEF), which has been established from funding from COSME to provide access to financial resources for SMEs in the Republic of Slovenia. This fund does not distinguish between ethnic and native entrepreneurs. Another example of funding by the European Union is the Kiútprogram in Hungary, which provides microfinance to groups of Roma entrepreneurs together with a variety of business development and administration services such as business training and specialist consultancy support.

In 2014, the Irish government published its first policy statement on Entrepreneurship (Department of Jobs, Enterprise and Innovation, 2014). Within the policy statement, 'migrants' are mentioned once and included in the strategic objective of 'Culture, Human Capital and Education' which states that Ireland must 'ensure that greater numbers of people, particularly in underrepresented cohorts such as females, youths, migrants and older people start and run their own business (ibid p.12). The policy document also makes a statement that ' $i t$ is important that policies to encourage entrepreneurship in Ireland take full account of the entrepreneurship potential of immigrants' (ibid p.21). Another measure the policy statement provides is to make Ireland an attractive location for immigrant entrepreneurs, in that efforts must be made to promote Ireland as an attractive location for internationally mobile start-ups. The policy statement does not specify any supports/training for ethnic/migrant entrepreneurs.

Another European policy in existence is the EU's 'Entrepreneurship 2020 Action Plan' which is based on three pillars: (1) to develop entrepreneurial education and training for business creation and growth; (2) to create the right ecosystem for entrepreneurship to prevail through the removal of barriers and supporting entrepreneurs throughout their lifecycle, and 
(3) developing role models and reaching out to specific groups (Borbás, 2015). When this policy was being devised the Commission explicitly designed it to facilitate entrepreneurship among migrants present in the EU and building on best practices developed in the Member states. Using the three pillars of the 'Entrepreneurship 2020 Action Plan' the following are examples of 'best practice' in Europe in terms of supports for ethnic entrepreneurs.

(1) Developing entrepreneurial education and training to start and scale a business:

According to Oliveira and Rath (2008), ethnic entrepreneurs often have a wide array of problems, notably a general lack of business management skills and competences, and often a poor grasp of the host country's language. While most EU funded entrepreneurship training programmes are aimed at the general population, targeted courses exist for ethnic entrepreneurs, varying from individual counselling to training courses, workshops, mentoring and (access to) credit. More specifically, IFS in Sweden funded by the EU, offers work experience programmes free of charge to migrant entrepreneurs. NYP in Finland co-funded by the European Social Fund and the City of Helsinki offers targeted training to immigrant entrepreneurs. Similarly, in Bologna Italy, the National Confederation of Craftsmanship organises specific training sessions, which aims to develop immigrants' skills in general management.

Ethnic entrepreneurs face several problems and challenges especially when lacking skills in the language of the host country. Challenges are encountered in communicating with potential customers, suppliers and financiers as well as learning about the regulations of the host country (Fairlie and Lofstrom, 2015). To overcome language problems many organisations have established EU funded training programmes designed to assist ethnic entrepreneurs i.e. IFS in Sweden offers newly arrived adults 'Swedish for Immigrants' which encompasses Swedish language classes and an introductory programme aimed at improving the immigrants' integration in the local labour market. Prizztech Ltd, a not-for-profit business 
development company located in the Satakunta region of Finland, offers EU-funded Finnish language and civic integration courses designed to improve immigrants' language skills and their understanding of the Finnish culture.

\section{(2) To create the right ecosystem for entrepreneurship}

According to the World Economic Forum (2013), there are eight pillars of an entrepreneurship ecosystem. One of these pillars includes a 'support system' and part of that support system is the provision of information services and advice. Numerous countries have specifically designed business associations and/or centres established to assist ethnic entrepreneurs (in Sweden there is the Sundsvall IFS Radgivnigscentrum; in Denmark there is the Copenhagen Business Centre and, in the UK, more specifically in Wolverhampton there is the Black Country Enterprise Centre). Ethnic entrepreneurs' lack of familiarity with rules can lead them to being unable to complete documents correctly, such as tax forms forcing them to hire accountants or other experts to act for them and, their lack of knowledge of various rules and regulations can result in fines for non-compliance. To overcome these problems, help desks and information points exist in many Business Centres throughout Europe, which provide information sheets and guides in various languages. There is evidence that some measures may be aimed exclusively at ethnic entrepreneurs, such as employing consultants in business centres with different cultural backgrounds or who speak minority languages, as is the case in Amsterdam, Frankfurt and Copenhagen. Advisers at the Chambers of Commerce in Frankfurt and Stuttgart focus specifically on ethnic entrepreneurs, for example, the Stuttgart Chamber employs a Turkish speaking contact to improve access for Turkish clients.

The World Economic Forum (2013) also highlights the importance of having funding and finance available to entrepreneurs. Accessing finance is a major challenge for anybody and particularly for ethnic entrepreneurs who are faced with a completely different financial environment to that which they experienced in their home country. Generalised funding 
programmes include the European Investment Fund (EIF), which provides entrepreneurs with access to finance. Some of the generic programmes under the EIF (2019) include the Baltic Innovation Fund, a $€ 52$ million fund in Lithuania, Latvia and Estonia which targets SMEs with high growth potential (European Investment Fund 2019). Additionally, the ESIF Fund-ofFunds Greece is a $€ 260$ million fund to boost entrepreneurship in Greece. Some countries through their local government have grants designed specifically for ethnic entrepreneurs. For example, ethnic entrepreneurs residing in Terrassa Spain, can earn six months worth of welfare money to establish a business through their grants scheme.

\section{(3) Developing role models and reaching out to specific groups}

The third pillar of the Entrepreneurship 2020 Action plan (Borbás, 2015) is to develop role models and enabling networking to occur. In Helsinki Finland for example, the Association of Helsinki Entrepreneurs have included targets to ensure that ethnic entrepreneurs are part of their association. In Stuttgart Germany, the organisation SELF supports networking for all entrepreneurs with a migrant background. In Wolverhampton England, there is both the Black and Minority Ethnic Forum and the Minority Ethnic Business Forum of Advantage West Midlands which offers ethnic entrepreneurs a networking forum. Platforms for networking among members of the same ethnic group also exist, such as the Turkish business platform XING in Stuttgart and the Turkish Association of Young Entrepreneurs in the Netherlands. Besides providing training and coaching services a few EU projects promote social networks of entrepreneurs. Some programmes include networking as one of its targets (for example Frankfurt; Amsterdam, Sundsvall, Turin and Stuttgart). In others, it is an unintended result of the programme. The German Unternehmer ohne Grenzen explicitly aims at promoting the incorporation of ethnic entrepreneurs into relevant local business networks and representing their interests to local policy makers. According to Desiderio and Mestres-Domenech (2011) ethnic entrepreneurs mainly cater for customers in their own [ethnic] enclave. Rath and 
Swagerman (2011, p.47) highlights that ethnic entrepreneurs need to be 'encouraged to break out of these captive markets', thus ethnic entrepreneurs need to adopt 'marketing methods' to attract customers from all communities therefore reaching out to other groups. In Finland (Turku) and Germany (Stuttgart), business centres offer advice to ethnic entrepreneurs on expanding into international markets and provide training programmes on marketing. Overall the number of interventions to foster social networking are explicitly small thus this pillar of the Action Plan requires more targeted measures to be put in place.

Another pillar of the WEF (2013) ecosystem is the provision of mentors. Entrepreneurs can also improve their skills through mentoring programmes. One scheme, which focuses specifically on migrants, is the 'Mentoring for Migrants' programme in Vienna Austria. This is organised by the Economic Chamber, the Austrian Integration Fund and the Employment Service and its goal is to support qualified migrants in getting into the labour market. Mentors and migrants are connected for six months for intensive interaction and mutual exchange is based on country of origin, language knowledge, and target markets of the enterprise.

\section{Research Methodology}

To answer the research question posed in this study i.e. 'Does Ireland provide the training and support necessary for entrepreneurship to occur within the ethnic communities that call Ireland home an internet search was conducted to identify what agencies and/or organisations were established to assist entrepreneurs. To identify these programmes, the secondary research included an internet search using a Boolean search approach. Programmes that contained words and phrases such as 'entrepreneur'; 'enterprise'; 'entrepreneurial'; 'training'; 'ethnic' or 'supports' were chosen. A total of 413 organisations were identified and they included government agencies, NGO's, private organisations and third level institutions. An online survey, which sought to get an understanding of the initiatives, training programmes and support services offered to ethnic entrepreneurs was sent to these organisations, with a 
reminder email reissued three days later. A total of 61 responses were received, which is a 15 percent response rate as identified in Table 2. The second cohort of respondents were ethnic entrepreneurs located in the Mid-West of Ireland. Two approaches were adopted to gain access to them. Firstly, an independent, non-profit, non-governmental organisation was contacted to assist with the study, and they invited several entrepreneurs to participate, which resulted in a response rate of 18. A further 55 ethnic entrepreneurs were identified through adopting a 'shoe leather' approach, which involved the research team canvasing businesses in Limerick City by knocking on doors with the expectation of identifying potential respondents. This culminated in a sample of 73 and a response rate of 49 percent $(n=36)$ was achieved as is evidenced in Table 2.

$<<$ INSERT TABLE 2 HERE $>>$

Ethnic entrepreneurs were asked to complete a questionnaire, which had five sections to it, and they were asked about their experience of the supports and services for establishing a business in Ireland. The first section examined the entrepreneur's profile. Demographic questions relating to gender, marital status, country of origin, education and their reasons for choosing Ireland as their new home were asked. The second section concerned the pre-start-up activities of the entrepreneur and they were questioned on idea generation, motivations and steps taken prior to start-up and the sources of finance used to start-up the business. They were then questioned on their interaction with support agencies at this stage of business development. Next respondents were asked about the training, if any, they participated in and if that training was funded by a support agency to identify who that agency was. Respondents were questioned on what other support/assistance/training could be provided by these agencies. For those who had not attended a training programme they were given a list of reasons why they did not attend and asked to choose all that applied. 
The third section examined the profile of the business which included questions on year of start-up; type of business established, employment numbers and what the business produced or if a service, what that was. Next, they were asked to describe how they differentiate their product and/or service from their key competitors and then questioned on whether they have subcontractors; an accountant; a solicitor and/or a contact in the bank that they use. The last part of this section questioned the respondents on their marketing plans and their marketing activities.

The fourth section examined their business skillsset. Fourteen business functions were presented, and they were asked to rate on a five-point scale, how well they carry out those functions. The follow-on question focused on nine tasks and the entrepreneur was asked whether they felt capable of completing those tasks. The next question provided the entrepreneur with a list of eight skills and they were asked if they felt they needed to improve on those skills. They were also given the opportunity to identify other skills that might not be listed in the question. Next, entrepreneurs were asked if, since their business started, they have participated in a training programme. The final question asked the entrepreneurs to identify what future training/skills they will/will not need, and they were given seven options to choose from.

The last section, section five, aimed to highlight the barriers/challenges entrepreneurs have faced in establishing and/or running their business. They were given a variety of statements, which covered business and operational challenges and were asked to identify if they were or were not a challenge to them. The respondent was then posed with an openended question asking them what challenges they believe they might face in growing their business.

Research Findings on Support Providers in Ireland 
Respondents to the support providers section of the study came from a variety of areas, 28 percent were private organisations, another 28 percent were government support agencies, 14 percent were from Universities and 'Other' accounted for 30 percent of responses. This category included responses from social enterprises, NGO's; a European funded business support organisation; a local development company and migrant support agencies. All respondents were asked if they supported entrepreneurs and 84 percent $(n=51)$ did and 16 percent $(n=10)$ did not. The ten respondents who indicated 'no' were further examined. The results showed that these respondents had written about supporting entrepreneurs but do not provide support on a day-to-day basis. Others historically supported entrepreneurs but no longer do. On further extrapolation only eight provided dedicated support to ethnic entrepreneurs, with the remainder indicating that ethnic entrepreneurs could avail of 'general entrepreneurship' supports. The respondents who provide targeted supports to ethnic entrepreneurs will be analysed in the remainder of the paper.

Of those who provide support dedicated to the ethnic entrepreneur $(n=8)$ five respondents categorised themselves as specialist organisations such as NGO's; migrant groups, social enterprises, two were from government support agencies and one respondent from a third level institution. Three respondents provide networking opportunities, six provide mentors specifically for ethnic entrepreneurs and only three provide financial assistance/grants for ethnic entrepreneurs. In six cases, ethnic entrepreneurs are not charged for the services they receive. Next respondents were questioned on whether they offer their services in the ethnic entrepreneur's own language and the results indicate an even split of 4:4, with some respondents indicating they would where necessary. In another situation the respondent indicated that 'sessions were presented in the native language of the presenter and then it was translated into other languages by co-presenters'. Lastly, respondents were asked if they think there are 'other services that should be offered to ethnic entrepreneurs' six replied positively. 
One service provider stated that additional support was required due to language barriers; and 'own language mentoring' was proposed by another. Another suggested a skill matching service to domestic companies and ethnic entrepreneurs.

\section{Established Ethnic Entrepreneurs in Ireland}

The findings for the established ethnic entrepreneurs as displayed in Table 3 are based on 36 valid responses, of which three-quarters were male. In terms of residency, an overwhelming majority have resided in Ireland for three or more years and were originally from Nigeria, Ghana, the Democratic Republic of Congo, Sudan, Uganda, Cameroon, India and Pakistan as well as Eastern European countries, which was represented mainly by Polish respondents. Respondents were asked what the motivation for locating to Ireland was and the key factor was family influences. Nearly all had a third level qualification, with three-fifths having a degree and one-fifth a Master qualification.

\section{$<<$ INSERT TABLE 3 HERE $>>$}

All respondents were the owner-manager of the business with the majority establishing the business between 2005 and 2010. Four-fifths had registered the business name; three-fifths were sole traders; with the remaining two-fifths being either a limited liability company or a partnership (see Table 4 for results). More than four-fifths of respondents work in the business full-time, with three-fifths providing a service and the remainder providing a product or a combination of the two. In three-fifths of cases respondents employed between two and 22 people full-time with the remainder being the sole employee of the business. Of these employees, slightly more than half were from the respondents own ethnic group; a third had Irish employees and one-fifth had employees from other EU states and ethnic groups.

\section{$<<$ INSERT TABLE 4 HERE $>>$}

In relation to their customer base, Table 4 identifies their customer base is predominantly local and most customers come from their own ethnic group or they have a mix between their 
own ethnic group and Irish customers. Differentiation strategies were varied with service and quality being the main contenders though price and the product itself were factors as well. Some anecdotal statements include:

There is no similar service in the area, so we are unique in that way. Our emphasis is on quality.

Quality of service, patient and work long hours and treat customer well.

We are passionate about our food, provide a very friendly service at a reasonable price.

The typical marketing activities they are currently engaged in is 'personal selling', with 'flyers' and 'advertising' coming a somewhat distant second and third. In the 'other' category, 'mobile texting', 'networking' and 'word of mouth advertising' were referred to. 'Branding as a marketing activity' rated poorly on the marketing activities scale along with 'market research' and 'attending trade fairs/exhibitions'. Just under a third of entrepreneurs do 'online marketing' and few do 'direct marketing' and 'PR'.

\section{Skills Assessment}

Questions were posed to the entrepreneurs requesting an assessment of their current skillset and their perceived future skills needs and Table 5 presents the results.

\section{$<<$ INSERT TABLE 5 HERE $>>$}

The results indicate that respondents believe that their skillset is quite good. The key business function they need assistance with is financial management as just under a third need assistance in 'balancing the books' and in 'writing a cash flow statement'. A third of entrepreneurs stated that they need assistance in 'designing a strategic plan for the business', with some respondents indicating no knowledge whatsoever of how to write a strategic plan. Another area that is a weakness in the entrepreneurs' skillset included 'conducting market research' as one third indicated that they 'need help on doing this' or they 'do not know how to do this'. Some twofifths of entrepreneurs indicated that 'branding' does not apply to them. Respondents were 
questioned on what training/skills they foresee they will need in the future and four key areas emerged: (1) understanding how to sell/promote online; (2) learning how to grow their business; (3) learning how to balance work and life; and (4) understanding how to write a business plan. Respondents were asked about the barriers they have faced, and they included getting access to finance; getting an overdraft and availing of grants. Two entrepreneurs further elaborated on their answers by saying:

Getting a bank overdraft is too stressful - I need help with the process.

Grants require one to do certain things that you will never fulfil. Too complicated. Additionally, making customers aware of their existence was a barrier as well as the expectation of providing credit to customers/suppliers. One entrepreneur stated:

A lot of business in Ireland is conducted on the strength of personal connections (nonprofessional or social networks), this can be a huge problem for a new business trying to establish a foothold in the early stages where the business principals are not local.

The last barrier was their gap in knowledge in terms of company registration and social welfare rights. Ethnic entrepreneurs were questioned on the advice received from government support agencies and/or if they attended training programmes offered by them. Figure 1 identifies the ethnic entrepreneur's knowledge of key bodies that support ethnic entrepreneurs.

\section{$<<$ INSERT FIGURE 1 HERE $>>$}

No respondent met with a representative from First Step though this might be due to the location of the First Step offices, which are in Dublin and the respondents businesses are in the Mid-West of Ireland. The City/County Enterprise Boards were the most popular organisation that entrepreneurs used prior to start-up. $\mathrm{FÁS}^{3}$ was the next most popular agency visited followed by Enterprise Ireland and PAUL Partnership/Ballyhoura/West Limerick Resources.

\footnotetext{
${ }^{3}$ FÁS is now called SOLAS
} 
Figure 2 indicates the results of what support they availed of from the enterprise support agencies.

\section{$<<$ INSERT FIGURE 2 HERE $>>$}

Over two-fifths had accessed the agencies for guidance and advice. Less than a fifth received mentoring; just under a third received assistance in writing a business plan; just over a third received advice on accessing funding options and one-fifth received support on conducting market research. Negative anecdotal responses were received on these providers and they include:

They must know ethnic issues first. We know what we want, but they don't. They can't even help us.

These bodies are the ones that need support - people there can't really help you, they haven't been in our shoes.

Furthermore, ethnic entrepreneurs prefer to use their own support networks rather than those of the support agencies with one entrepreneur saying 'I have many friends in other countries they know a lot about our business. These are the people I trust to help with troubled events. One entrepreneur believed the support agencies are unable to support ethnic entrepreneurs because they are unaware of the issues they face. The outcome from this question would indicate that the participating ethnic entrepreneurs in this study are not availing of the full spectrum of services available to them which are offered by these agencies and that there are barriers to using the services. Entrepreneurs were questioned on whether they took part in business training programmes offered by these agencies and only one-fifth of entrepreneurs indicated they had availed of the service. When questioned on what other support/assistance/training would be helpful suggestions such as, more financial support and advanced training in marketing and sales were given. For those who did not participate in a 
training programme offered by the support agencies they were asked their reasons and Figure 3 indicates the results.

\section{$<<$ INSERT FIGURE 3 HERE $>>$}

Awareness of the existence of such training programmes and/or being available was the primary reason why the entrepreneurs did not participate, and others felt that it did not suit their needs. The reasons for not participating ranged from knowing the agency would not know how to support them; their belief that they would be expensive and not tailored to their needs and lastly a respondent stated that she had poor English and didn't have the confidence to attend.

Poor English when I started the business - didn't have the confidence to go on a training course.

I would imagine the courses are expensive and if they are not tailored to my business ideas then I do not think they would be good for me.

\section{Conclusions}

This paper examined if the training and support necessary for entrepreneurship to occur within ethnic communities exists in Ireland. The EU has allocated funds to support the provision of tailored supports and programmes for ethnic entrepreneurs. Evidence was provided which highlighted various EU policies designed for entrepreneurial support, with examples of tailored initiatives for ethnic entrepreneurs throughout Europe. There has been a fundamental shift in the design of policies targeting entrepreneurs in Europe, gone from hard, infrastructure-based programmes to a soft-policy approach focusing on the individual. Most policies are implemented with integrated suites of programmes that include entrepreneurship training, coaching and mentoring and financial support, which are directed more towards the individual (European Commission, 2000; Vonk and Ribbink, 2008). These support packages are typically provided in a progressive manner with an increasing intensity of support provided to those who have demonstrated a quality business idea and potential for success. The quality of self-employment is highly heterogeneous and not all forms of self-employment should be 
supported by public policy. Policy makers should be aware of the risks and opportunity costs and weigh them against the benefits of successful businesses creation for groups that are underrepresented and disadvantaged in the labour market. Caution is also needed when supporting entrepreneurs because entrepreneurship is not suitable for everyone. An area for further research would be to conduct a cross-country analysis of the training programmes tailor made for ethnic entrepreneurs.

Ireland has a long history of being an entrepreneurial nation and has been lauded for opening its doors to immigrants who have suffered because of war and conflict. However, when one analyses the targeted supports for ethnic entrepreneurs the results are poor. Few service providers have targeted support for the ethnic entrepreneur. Of the 61 support agencies who responded only eight had targeted supports for ethnic entrepreneurs and these providers were in some rural parts of Ireland. Since large concentrations of ethnic entrepreneurs are mostly found in large cities or in metropolitan areas, it is recommended that the geographic spread should be narrowed, and providers located in ethnic 'hot spots'. Examining the lack of targeted support for the ethnic entrepreneur warrants further research in the Irish context.

It is further recommended that the Irish government review what is on offer on mainland Europe and consider replicating some of those initiatives and subsequently researching the impact of the initiatives. By not developing tailored programmes the implications for the ethnic entrepreneur are vast and include possibly missing out on grants that are specifically available for entrepreneurs such as those available through the EIF fund. And, maybe having to go 'underground' to use money lenders for start-up funds.

Some of the measures are part of a governmental policy to reach the most vulnerable or deprived groups, like the Roma (the Hungarian case). In some cases, the measure focuses more generally on the labour market position of immigrants by providing general professional training (NYP in Finland). In Ireland when the government agencies were contacted and asked 
about their understanding of the ethnic enclaves, no definitive answer could be provided on their makeup. It is therefore recommended that regional support agencies get to know and understand the ethnic groupings in their region and then better tailor their supports such as understanding the language needs of the ethnic entrepreneurs in their locality.

The findings of this study identify that ethnic entrepreneurs are well educated and have formally registered their business. The businesses tended to be the ethnic entrepreneur's sole source of income though in many cases they were employers of up to 22 employees. The businesses are typically service orientated with customers coming from their own ethnic enclave but also native customers as well. Several respondents to this study were not aware of the training that is available in Ireland, and this could be due to a language problem or because of their limited social networks. There is a practice implication of this result: low levels of awareness should be investigated as possible indicators of poor communication strategies by service providers in Ireland. Support providers need to communicate with the ethnic communities and understand their training needs and design programmes around those outcomes. Furthermore, since most ethnic entrepreneurs arrive into a country with limited possessions, it is recommended that a highly subsidized service be provided and where possible, like our European counterparts, completely free.

In Ireland, few support providers provide networking opportunities for ethnic entrepreneurs and the examples of European initiatives should be considered as best practice that can be adopted in Ireland. An area of further research would be to examine, from a crosscountry perspective, how networking opportunities or their lack of networking impacts on the operations of an ethnic entrepreneur. The respondents for this study were from many countries throughout the world and therefore Ireland does not have enough of a concentration of one ethnic minority grouping so, though it is recommended to promote the service of service 
providers to ethnic entrepreneurs, it is not recommended to name that service provider after one specific ethnic grouping, as is being done in Europe.

In Europe, many business centres, which are run by the City and supported by EU funds, provide consultants who are fluent in minority languages and are aware of ethnicity issues and cultures. Language support was not a priority for the service providers in Ireland even though it is known that language is a major barrier for foreign nationals (Volery 2007). It is recommended that leaflets and/or webpages be offered in multiple languages to cater for the various ethnic groupings that now reside in Ireland. The implications of this is that more ethnic entrepreneurs might consider self-employment as a career option since they are more informed and also they may reach out to service providers if they know they can be heard and understood in their native language.

Assistance in getting access to finance is a service provided by many on mainland Europe however few programmes were evident in the Irish context and again service providers need to look to their European counterparts for examples of best practice that could be incorporated into the Irish financial system. If anything, COSME needs to be promoted better in Ireland as no service provider mentioned they were funded by this initiative.

What can be derived from this analysis and in comparing the primary research results with the EU analysis, one can conclude that Irish service providers need to provide additional services to ethnic entrepreneurs to be on par with their EU counterparts. At a minimum, service providers in Ireland should provide the following: general and targeted training programmes; services through minority languages; mentoring (with native born and ethnic entrepreneurs); marketing assistance; networking (implicitly at least if not explicitly); assistance with finding a business location; open doors to the Business Incubation Centres affiliated with $3^{\text {rd }}$ level institutions; and provide assistance in getting access to finance either through a microcredit scheme operated by the service provider themselves or liaising with the financial institutions 
on packages to offer ethnic entrepreneurs. Furthermore, service providers in Europe encourage ethnic entrepreneurs to join local business networks such as the Chambers of Commerce. This is not encouraged as much in the Irish context. Therefore, it is recommended that ethnic entrepreneurs should be encouraged to join such associations.

If Ireland wants to continue being known as the 'land of a hundred thousand welcomes' and be able to support the much-anticipated asylum seekers who may choose entrepreneurship as a career option, it needs to consider the adoption of the recommendations of this study and provide better tailored training and services for the ethnic entrepreneur.

\section{REFERENCES}

Ahmad, N. and Seymour, R.G. (2008), “Defining entrepreneurial activity: Definitions supporting frameworks for data collection", available at: http://www.oecd.org/officialdocuments/publicdisplaydocumentpdf/?doclanguage $=$ en $\&$ cote $=\mathrm{S}$ $\underline{\mathrm{td} / \mathrm{doc}(2008) 1}$ (accessed 2 June 2018).

Basu, A. and Altinay, E. (2002), “The interaction between culture and entrepreneurship in London’s immigrant businesses”, International Small Business Journal, Vol. 20 No.4, pp. $371-93$.

Basu, A., Yeung, B. and Casson, M. (2008), The Oxford Handbook of Entrepreneurship, Oxford Handbooks.

Birdthistle, N. (2012), An Examination of Ethnic Entrepreneurship in the Mid-West Region of Ireland, Doras Luimní: Limerick, Ireland.

Borbás, L. (2015) The Role of SMEs in the European Entrepreneurship Policy, Obuda University: Hungary. 
Central Statistics Office (2017), "Population and migration estimates: April 2017”, available at:

http://www.cso.ie/en/releasesandpublications/er/pme/populationandmigrationestimatesapril20 $\underline{17 /}$ (accessed 26 April 2018).

Central Statistics Office (2018), "Population and Migration Estimates: April 2018”, available at:

https://www.cso.ie/en/releasesandpublications/er/pme/populationandmigrationestimatesapril2 018/ (accessed 3 February 2019).

Central Statistics Office (nd), “Census of population 2016 - profile 11 employment, occupations and industry", available at: http://www.cso.ie/en/releasesandpublications/ep/pcp11eoi/cp11eoi/lfnmfl/ (accessed 26 April 26 2018).

Chaganti, R. and Greene, P. (2002) "Who are ethnic entrepreneurs?”, Journal of Small Business Management, Vol. 40 No. 2, pp. 126-43.

Chrysostome, E. and Lin, X. (2010), “Immigrant entrepreneurship: Scrutinizing a promising type of business venture", Thunderbird International Business Review, Vol. 52 No. 2, pp. 7782.

Chrysostome, E. (2010), “The success factors of necessity immigrant entrepreneurs: In search of a model”, Thunderbird International Business Review, Vol. 52 No. 2, pp. 137-152.

Department of Jobs, Enterprise and Innovation (2014), National Policy Statement on Entrepreneurship in Ireland, Department of Jobs, Enterprise and Innovation, Dublin, Ireland.

Desiderio, M.V. and Mestres-Domenech, J. (2011), 'Migrant entrepreneurship in OECD Countries', in OECD (ed), International Migration Outlook: SOPEMI 2011, OECD Publishing, Paris, France, pp.139-203 
European Commission (2000), Young Entrepreneurs, Women Entrepreneurs, Ethnic Minority Entrepreneurs and Co-Entrepreneurs in the European Union and Central and Eastern Europe, Centre for Enterprise and Economic Development Research, Middlesex University Business School, UK.

European Investment Fund (2019), "European Investment Fund", available at: http://www.eif.org/what we do/index.htm, (accessed 3 February 2019).

Fairlie, R. W. and Lofstrom M. (2015), “Immigration and entrepreneurship", available at: http://www.cesifo-group.de/DocDL/cesifo1_wp5298.pdf, (accessed 1 June 2018).

Fitzsimons, P. and O’Gorman, C. (2009), Entrepreneurship in Ireland: 2008. Dublin City University, Dublin, Ireland.

Hutchinson J. and Smith A.D. (1996), Ethnicity, Oxford Press University, Oxford, England. International Protection Office (2019), "Monthly statistical report: November 2018”, available at: http://ipo.gov.ie/en/ipo/pages/statistics (accessed 14 January 2019).

Irish Refugee Council (2018), "Statistics Republic of Ireland”, available at: http://www.asylumineurope.org/reports/country/republic-ireland/statistics (accessed 30 May 2018).

Keh, H.T., Foo, M.D. and Lim, B.C. (2002), “Opportunity evaluation under risky conditions: The cognitive process of entrepreneurs", Entrepreneurship Theory and Practice, Vol. 27 No. 2, pp. 124-148.

Kurtoglu, K. (2007), "Immigrant entrepreneurship in Austria”, in Dana, L.P. (Ed.), Handbook of Ethnic Entrepreneurship: A Co-evolutionary view on Resource Management, Edward Elgar, Gloucestershire, pp. 425-432. 
Lally, C. (2018), "Significant increase in numbers seeking asylum in Ireland", available at: https://www.irishtimes.com/news/crime-and-law/significant-increase-in-numbers-seekingasylum-in-republic-1.3465992 (accessed 30 May 2018).

Lassalle, P., Hughes, M. and Hughes-Helinsk, E. (2010), "Re-theorising ethnic entrepreneurial strategies", available at: https://www.isbe.org.uk/ethnicentrepreneurialstrategies (accessed 24 September 2011).

Mac Cormaic, R. (2008), “Warning on dangers of migrant segregation”, The Irish Times, 8 October, p. 1

Mahieu, B., Brown, N., Fikkers, D.J.; Rosemberg, C., Roman, L., Sadeski, F. and Zegel, S. (2017), Interim evaluation of the COSME programme, European Commission: Brussels.

McMullen, J.S. and Shepherd, D.A. (2006), "Entrepreneurial action and the role of uncertainty in the theory of the entrepreneur", Academy of Management Review, Vol. 31 No. 1, pp. 132152.

Muchitsch, W. (2006) “Austrian refugees in Ireland 1938-1945”, in Holfter, G. (Ed.), GermanSpeaking Exiles in Ireland 1933-1945, Rodopi, New York, NY.

Ní Laoire, C. (2004), “Coming 'home’: A geography of recent return migration to the republic of Ireland", paper presented at the $2^{\text {nd }}$ International Population Geographies Conference, 1114 August, St. Andrews, Scotland.

OECD (2010), Entrepreneurship and Migrants, Report by the OECD Working Party on SMEs and Entrepreneurship, OECD, Paris.

Q8. This should read as follows:

Oliveira, C.R., and Rath, J. (Eds), (2008), 'Immigrant Entrepreneurship”, Migrações Journal, Special Issue, No. 3, ACIDI, Lisbon, October. 
Pang, C.L. and Rath, J. (2007), "The force of regulation in the land the free: The persistence of Chinatown, Washington DC as a symbolic ethnic enclave", in Ruef, M. and Lounsbury, M. (Eds.), The Sociology of Entrepreneurship, Elsevier, New York, pp. 191-216.

Portes, A. (1995), "Latin American class structure, their composition and change during the last decades", Latin American Research Review, Vol. XX No. 3, pp. 7-39.

Rath, J. (2006), “Immigrant entrepreneurship: Creating new opportunities,” paper presented at the UN Symposium on International Migration and Development, 30 June, Turin, Italy, available at: http://www.un.org/esa/population/migration/turin/Turin Statements/RATH.pdf (accessed 22 June 2018).

Rath, J. (2010), “Ethnic entrepreneurship: Concept paper", available at: http://www.eurofound.europa.eu/publications/htmlfiles/ef1039.htm (accessed 3 Oct 2011).

Rath, J. and Swagerman, A. (2011), Promoting Ethnic Entrepreneurship in European Cities, Publications Office of the European Union, Luxembourg.

Reception and Integration Agency (2011), "Monthly statistics report: December 2011", available at:http://www.ria.gov.ie/en/RIA/RIADec(A4)2011.pdf/Files/RIADec(A4)2011.pdf (accessed 2 June 2018).

Reynolds, P., Bosma, N., Autio, E., Hunt, S., De Bono, N., Servais, I., Lopez-Garcia, P. and Chin, N. (2005), “Global entrepreneurship monitor: Data collection design and implementation 1998-2003”, Small Business Economics, Vol. 24 No. 3, pp. 205-231.

RETHE (2010), Orthodox Approach Document, European Regional Development Fund, Brussels, Belgium.

Rusinovic, K. (2008), "Moving between markets? Immigrant entrepreneurs in different markets", International Journal of Entrepreneurial Behaviour \& Research, Vol. 14 No. 6, pp. $440-454$. 
Volery, T. (2007), “Ethnic entrepreneurship: A theoretical framework,” in Dana, L.P. (Ed.), Handbook of Research on Ethnic Minority Entrepreneurship: a Co-evolutionary View on Resource Management, Edward Elgar, Cheltenham, England, pp. 30-41.

Vonk, J., and Ribbink, G. (2008) "Promoting ethnic minority entrepreneurship in Europe", available at:

http://ec.europa.eu/enterprise/entrepreneurship/support measures/migrant/index.htm (accessed 16 Nov 2011).

Ward, T. (2001), “Immigration and residency in Ireland", available at: http://migration.ucc.ie/cdvec.htm (accessed 16 Nov. 2011).

Waldinger, R., Aldrich, H. and Ward. R. (1990), Ethnic Entrepreneurs: Immigrant Business in Industrial Societies, Sage, London, United Kingdom.

World Economic Forum, (2013), Entrepreneurial Ecosystems Around the Globe and Company Growth Dynamics, World Economic Forum: Switzerland. 